\title{
EVALUATION OF MONITORING HYPERTENSION CASE BASED ON NINE SURVEILLANCE ATTRIBUTES IN JOMBANG DISTRICT HEALTH OFFICE IN 2018
}

\author{
Dewi Lestari \\ Department of Epidemiology, \\ Faculty of Public Health, Airlangga University, Surabaya, Indonesia \\ Correspondence Address: Dewi Lestari \\ E-mail: dewi.lestari-2015@fkm.unair.ac.id
}

\begin{abstract}
Hypertension is still a global problem, therefore, even affecting the citizens of Indonesia. Among 10 most common diseases in Jombang regency, hypertension was ranked second in 2017. One of the efforts in overcoming hypertension was by monitoring hypertension cases through Noncommunicable Diseases (NCD) surveillance system strengthening. However, the completeness of the MSS hypertension reports in Jombang region was low.The purpose of this study was to evaluate the monitoring of hypertension cases based on surveillance attributes in the Jombang District Health Office throughout 2018. This study was conducted using the qualitative evaluation method. The research subject was NCD surveillance, specifically in monitoring hypertension cases in the Jombang District Health Office. The determination of the informants used purposive sampling. The research informants consist of NCD officers in Jombang District Health Office, and NCD officers in 2 selected primary healthcare centers. The data collection technique used interview guidelines and document observation where data analysis was performed descriptively. The results show in the assessment of surveillance attributes of simplicity, acceptability, positive predictive value, data quality, and stability the results were low. While, flexibility, sensitivity, representativeness, and timeliness cannot be assessed. The conclusion was that the assessment of the surveillance attributes was quite good, but there are still obstacles in its implementation, namely incomplete reports, no attendance records, and so on. This study suggests to implement attendance records in each unit allowing the reported data to be used for planning in preventing hypertension.
\end{abstract}

Keywords: evaluation, hypertention, surveillance attribute.

\section{ABSTRAK}

Hipertensi masih menjadi masalah di Indonesia bahkan di dunia. Penyakit hipertensi menempati urutan kedua dari 10 penyakit terbanyak di Kabupaten Jombang pada tahun 2017. Salah satu upaya penanggulangan penyakit hipertensi yaitu dengan pemantauan kasus hipertensi melalui penguatan sistem surveilans PTM. Namun kelengkapan laporan SPM hipertensi di Kabupaten Jombang masih rendah. Penelitian ini bertujuan untuk mengevaluasi pemantauan kasus hipertensi berdasarkan atribut surveilans di Dinas Kesehatan Kabupaten Jombang tahun 2018. Penelitian ini merupakan penelitian kualitatif dalam bentuk evaluatif. Subjek penelitian adalah surveilans PTM khusus pada pemantauan kasus hipertensi di Dinas Kesehatan Kabupaten Jombang. Penentuan informan menggunakan sampling pusposif. Informan penelitian terdiri dari petugas PTM di Dinas Kesehatan Kabupaten Jombang dan petugas PTM di 2 puskesmas terpilih. Teknik pengumpulan data menggunakan pedoman wawancara dan observasi dokumendi mana analisis data dilakukan secara deskriptif. Hasil penelitian menunjukkan penilaian pada atribut surveilans yaitu kesederhanaan, akseptabilitas, nilai prediktif positif, kualitas data, dan stabilitas hasilnya rendah. Sedangkan fleksibilitas, sensitivitas, representatif, dan ketepatan waktu tidak dapat dinilai. Kesimpulan dari penelitian ini adalah penilaian pada atribut surveilans sudah cukup baik, namun masih ada hambatan dalam pelaksanaannya, yaitu kelengkapan laporan masih rendah, belum diadakan catatan absensi, dan lain sebagainya. Saran yang dapat diberikan adalah menerapkan catatan absensi di masing-masing unit dalam pelaporan, agar data yang dilaporkan dapat digunakan sebagai bahan perencanaan untuk melakukan penanggulangan penyakit hipertensi.

Kata Kunci: evaluasi, hipertensi, atribut surveilans.

\section{INTRODUCTION}

Hypertension is classified as a noncommunicable disease (NCD) that is still quite a prominent health problem globally, including in Indonesia. Data from the World Health Organization (WHO) show almost 9.4 million people die every 
year from hypertension. In 2008, the prevailing number of hypertension cases in the world affects around $40 \%$ of adults aged 25 years and above. Indonesia was ranked second after Myanmar due to the highest prevalent number of cases at $42.7 \%$ in males and 39.2\% in females (WHO, 2013).

The results of a national survey of blood pressure measurements in basic health research in 2018, found the prevalence of hypertension has increased by $34.11 \%$ compared to $2013(25.8 \%)$ and 2007 (31.7\%). East Java is one of the provinces which has a prevalence of hypertension above the national average of $36.32 \%$ (Indonesian Ministry of Health, 2018). The number of hypertension cases in East Java totaled $15.16 \%$ in 2015 , then further plummeting to $13.47 \%$ in 2016 . The presence of hypertension in the East Java province based on the average measurement of blood pressure of the population was equal to 18 years old, has experienced an increase in 2017 and 2018. The number in 2017 increased to $20.43 \%$ further rising in 2018 to $22.71 \%$ (East Java Provincial Health Office, 2019).

Jombang was a regency with the third lowest recorded cases of hypertension in East Java in 2018. However, seen from the regions statistics, the prevalence of hypertension based on the results of blood pressure measurement in the 18-year-old population has increased to $9.80 \%$ in 2018 compared to the previous year of $7.85 \%$ (Jombang District Health Office, 2019). Additionally, based on the $1^{\text {st }}$ Monthly Disease Report (MDR) of primary healthcare centers in 2014-2016, hypertension was ranked third out of 10 most common diseases in Jombang. In 2017, hypertension increased to second of the 10 positions. Finally, since 2018, it has been ranked first. Thus, it has become the number 1 disease in the NCD category of the top 10 diseases in Jombang (Jombang District Health Office, 2019). This contradicts the strategic plan objectives of the Jombang District Health Office to increase life expectancy for the period of
2014 to 2018. (Jombang District Health Office, 2018). However, hypertension remains still a serious problem in Jombang.

Prevention towards hypertension needs to be conducted. One method was by strengthening the NCD surveillance system in order to monitor hypertension cases better. NCD surveillance plays a prominent role in decision-making related to what programs will be conducted to deal with the rise of hypertension. If it can be diagnosed early and treated appropriately, it will reduce the risk of complications (Peberdy, 2016).

One of the indicators of surveillance performance was to include the accuracy and completeness of the report (Indonesian Ministry of Health, 2014). Based on a preliminary study conducted with the NCD program manager in the Jombang District Health Office, there were obstacles in the implementation of NCD surveillance with the incomplete reporting of the MSS (Minimum Service Standards) of hypertension. Six primary healthcare centers allegedly did not report the MSS of hypertension completely in 2018. Only 2 primary healthcare centers within the region submitted their reports completely.

The MSS report on hypertension was an important instrument in assessing whether or not the hypertension services provided are in accordance with the set standards. If there are still several primary healthcare centers that do not report their MSS properly, the data generated cannot correctly represent the Jombang regency in achieving the target of MSS for hypertension which was $100 \%$. Therefore, there are still problems regarding the completeness of the report. If the the report still has issues there will be a delay in the decision-making process of the regional government in dealing with hypertension. An effort to achieve the MSS target, in this context, was to evaluate the monitoring of hypertension cases through NCD surveillance. Evaluation activities are very useful in providing recommendations in 
order to improve the quality of the surveillance.

The assessment of surveillance activity can be done through the 9 surveillance attributes that include simplicity, flexibility, acceptability, sensitivity, positive predictive value, representativeness, timeliness, data quality, and stability (CDC, 2013). Supported by previous research conducted by Rahmayanti and Hargono (2017) on the implementation of noncommunicable disease risk factors surveillance in posbindu Surabaya based on surveillance attribute, the NCD risk factor surveillance system was not yet representative of the subject and place variables. Moreover, the assessment of flexibility and positive predictive value was unmeasurable. While research conducted by Burchard (2017) on the evaluation of the South Australian Monitoring and Surveillance System (SAMSS) to monitor chronic diseases and risk factors found the assessment of flexibility, acceptability, and representation was still low.

Based on surveillance attributes in Jombang District Health Office in 2018, results of the study mentioned previously show that monitoring evaluation of hypertension cases was still necessary to find the obstacles. This study was conducted to evaluate the monitoring of hypertension cases based on surveillance attributes in Jombang District Health Office in 2018 .

\section{METHOD}

This study used the qualitative methodology in the form of evaluation research to assess the current or ongoing health programs. Therefore, it can be applied as a program improvement. Triangulation in this research used documented observation as confirmation of the results from interviews with the informants.

This study was conducted at the Jombang District Health Office, Pulo Lor
Primary Healthcare Center, and Cukir Primary Healthcare Center from March to July 2019. The research subjects were surveillance of noncommunicable diseases in monitoring hypertension cases at the Jombang District Health Office in 2018. The informants were selected through purposive sampling technique with the results of 1 NCD officer from the Jombang District Health Office and 2 NCD officers at 2 other selected primary healthcare centers. The determination of the chosen primary healthcare centers was based on the highest and lowest completeness criteria in 2018 based on a proposal from the NCD officers in the Jombang District Health Office. As a result, the selected were the Pulo Lor and Cukir Primary Healthcare Centers.

However, during the data gathering process, the research was conducted with 5 informants unlike the original plan of only 3 . This was due to the recruitment of new NCD officers in 2019 within the duration of the study. The change of NCD officers occurred at the Jombang District Health Office and Cukir Primary Healthcare Center, resulting in the total of $2 \mathrm{NCD}$ officers from Jombang District Health Office, 1 from Pulo Lor Primary Healthcare Center, and 2 from Cukir Primary Healthcare Center.

The research variables involved 9 surveillance attributes such as simplicity, flexibility, acceptability, sensitivity, positive predictive value, representativeness, timeliness, data quality, and stability.

This study used both primary and secondary data. The primary data were obtained from interviews with the informants, while the secondary data were obtained from document observations. The data analysis was presented descriptively through depicting the actual monitoring situation of hypertension cases where then the results were evaluated based on 9 surveillance attributes using narration and tables. This research was approved by the 
ethics commission with No. 159/EA/KEPK/2019.

\section{RESULTS}

\section{Overview on The Monitoring of Hypertension Cases Based on Surveillance Attributes}

\section{Simplicity}

Simplicity was assessed from the simplicity and convenience of the officers in understanding the definition of hypertension cases, collecting hypertension data, recording, analyzing, and reporting the data. The definition of hypertension cases in both primary healthcare centers was found to be easily understood. This was supported by the conclusions of the interview results which reinforced that the definition of a hypertension case was clear. The result of blood pressure measurement was more than or equal to $140 / 90$ millimetre of mercury $(\mathrm{mmHg})$. In the data retrieval and hypertension case collection, recording, analysis, and reporting of data, both stated that they did not experience difficulties. However, Cukir Primary Healthcare Center experienced difficulty in recapitulating the MSS of hypertension form and NCD 42 case form. This was quoted from the interview extract as follows.

"pelaporane SPM hipertensi uangel aku rekape per desa, jadi aku langsung rekap 1 bulan total, ....susah niteni di simpus, kalau ngisi di pelaporan kasus ptm itu ya kesulitan, karena diagnose-diagnose". (translated into: "it is difficult and complicated to report the MSS of the hypertension as I have to recap the data per village, so I have to recap the whole month worth of data. It is very difficult to enter it to the central system, thus I found It difficult to fill in the reports as there are many diagnoses complete")

The statement was supported by an older officer from the Jombang District Health Office who stated:

"kalau yang rumit biasanya rekap ptm itu, soalnya per usia per jenis kelamin membutuhkan waktu lama dalam pengisiannya". (translated into: "The complicated one is the NCD recap because we have to fill the form for each age and gender; therefore, it takes a long time to finish")

The definition of a hypertension cases at Jombang District Health Office was also easily understood. The collection and analysis of hypertension data became slightly difficult when there was a primary healthcare center that was late or did not report at all.

It was concluded that simplicity attribute in the monitoring of hypertension cases in the Jombang District Health Office in 2018 was considered inadequate.

\section{Flexibility}

Flexibility was examined through the ability of surveillance to monitor hypertension cases and adjust to changes that occur without additional time, energy, and cost. Based on the results of the interviews, it was found that throughout 2018, both primary healthcare centers and Jombang District Health Office had never experienced changes related to the information required, including the report forms and changes in operational conditions such as the reporting order. Therefore, the flexibility in the monitoring of hypertension cases in 2018 could not be assessed.

\section{Acceptability}

Acceptability was assessed from the willingness of the officers to provide accurate, complete, and timely data in the reporting and the presence of other parties who use the hypertension data and the feedback given to the data source.

The willingness of the primary healthcare center officers to provide accurate, complete and timely data remains to be overflowing with difficulties. This can be seen from only $50 \%$ of the reports collected by the Pulo Lor Primary Healthcare Center were completed. On the other hand, Cukir Primary Healthcare 
Center had difficulty in recording hypertension data, thus the data collected were incomplete and not reported regularly as required. Based on the interviews, data from the monitoring of hypertension cases in both primary healthcare centers could be used for cross/inter programs, such as nutrition programs and other sectors, such as in universities as research material. This was supported by a statement of one of the officers as follows.

"lintas program biasanya yang memanfaatkan dari gizi, ya itu buat laporan, kalau tindak lanjutnya belum, sedangkan lintas sektor yang memanfaatkan data hipertensi biasanya dari mahasiswa untuk penelitian". (translated into: "The interprogram that used this is usually for the nutrition department, for example for report. But we have not yet recive the follow up. As for other sectors that used the reports usually comes from university students for research")

However, the feedback given to the data source has not been implemented by the two primary healthcare centers.

The willingness of Jombang District Health Office officers to provide accurate, complete, and timely data also faces some issues due to irregular and improper data reporting. This can be seen from the completeness of the reports collected by the Jombang District Health Office adding up to only $66.9 \%$. The data of the monitoring of hypertension cases could be utilized by other programs, such as nutrition programs and other sectors equivalent to higher education institutions. Jombang District Health Office also provides feedback to primary healthcare centers which have reported hypertension cases. Feedback was given in the form of a presentation for the head of the primary healthcare center and NCD programmers. Besides presentations, data confirmation was usually conducted to ensure the data sent was correct.

In conclusion, the acceptability in the implementation of monitoring of hypertension cases in the Jombang District Health Office in 2018 was low.

\section{Sensitivity}

Sensitivity, in this context, was the proportion of the population that correctly identifies the population with the disease. Sensitivity can be assessed by comparing the data of hypertension cases obtained by the surveillance with those from other means such as health surveys. In 2018, both of the primary healthcare centers and the Jombang District Health Office did not conduct a health survey. Thus, the sensitivity of the hypertension case data could not be assessed, as the surveillance data could not be compared with other data of the population.

\section{Positive Predictive Value}

Importantly, the data referred/confirmed to hospitals were 234 cases, while recieved confirmation from the hospitals were only 139 cases. Thus, positive predictive value of hypertension cases in the Pulo Lor Primary Healthcare Center in 2018 was only $59.4 \%$. Following are the results of the calculation of positive predictive value of hypertension cases in the Pulo Lor Primary Healthcare Center in 2018:

Table 1. Positive Predictive Value Calculation Results on the Hypertension Cases in Pulo Lor Primary Healthcare Center in 2018

\begin{tabular}{llll}
\hline \multirow{2}{*}{$\begin{array}{c}\text { Detected By } \\
\text { The }\end{array}$} & \multicolumn{2}{c}{$\begin{array}{c}\text { Corfimation } \\
\text { of The } \\
\text { Reffered Data }\end{array}$} & \\
\cline { 2 - 4 } Surveillance & Yes & No & \\
\hline Yes & $\mathrm{A}=$ & $\mathrm{B}=$ & $\mathrm{A}+\mathrm{B}=$ \\
No & 139 & 95 & 234 \\
\hline & $\mathrm{C}=$ & $\mathrm{D}=$ & $\mathrm{C}+\mathrm{D}=$ \\
\hline & $\mathrm{A}+\mathrm{C}=$ & $\mathrm{B}+\mathrm{D}=$ & Total \\
\hline
\end{tabular}

Predictive Value Positive $=$ $\mathrm{A} /(\mathrm{A}+\mathrm{B}) \times 100 \%=139 / 234 \times 100 \%$ $=59,4 \%$ 
Positive predictive value was the proportion of the population identified as a case by the surveillance system where it was possible to find people suffering from an illness among the suspects. Positive predictive value can be assessed by comparing the data of hypertension cases referred to the hospital with the data referred back from the hospital. Positive predictive value in 2018 was assessed based on document observations in only the Pulo Lor Primary Healthcare Center.

\section{Representativeness}

Representativeness was assessed if the surveillance data could describe the trend of hypertension cases in an area correctly, based on the people, place, and time. However, this variable requires data from outside surveillance to act as a measure, in this case the health survey data.

Through the interviews with the informants from both of the primary healthcare centers and the Jombang District Health Office, it was said that a health survey was not conducted in 2018. Therefore, the data from the monitoring of hypertension cases obtained could not be assessed as there was no outside data use as comparison. This concludes that the data cannot represent the population.

\section{Timeliness}

Timeliness was assessed through comparing reports that should be received with the reports received on time according to predetermined deadlines. Calculating timeliness of reporting was done through attendance records. However, based on the results of the interviews with the primary healthcare center officials, it was said that currently in the monitoring of hypertension cases there was no punctual record in the reports. This is the statement from one of the officers as follows.

"untuk pelaporan tidak pernah absen tanggal, taunya cuma bulan ini dia (primary healthcare center) laporan apa nggak...". (translated into: "for the reporting we dont have any attendance record, we only know wether they report in the current month or not")

This implies that the timeliness in the monitoring of hypertension cases in the primary healthcare centers and in the Jombang District Health Office in 2018 could not be assessed.

\section{Data Quality}

Data quality was assessed by comparing reports with other reports that have complete variables related to hypertension. Based on interviews and document observations of the two primary healthcare centers, the reports which had the best quality of data belong to the Pulo Lor Primary Healthcare Center. The data from Cukir Primary Healthcare Center were incomplete because it did not collect and record hypertension cases from its NCD posts. However, the completeness of the report in Pulo Lor Primary Healthcare Center in 2018 remained at 50\%. From the document observation, the quality of the data in the Jombang District Health Office was assessed from the completeness of the reports received from each primary healthcare center. The completeness of the reports in 2018 was $66.9 \%$.

In conclusion, the data quality in the monitoring of hypertension cases, both in the Pulo Lor Primary Healthcare Center and the Jombang District Health Office, in 2018 was considered low. This was due to the fact that the completeness of the reports was less than $80 \%$.

\section{Stability}

The stability of the hypertension data could be assessed in terms of its reliability through collection/reporting, proper storage of the data, and its availability at any time. From the interviews with both primary healthcare centers, The Cukir Primary Healthcare Center experienced some problems in storing the data of hypertention case. 
In 2018, the data storage device was error and caused the loss of data. To recover it, the officer had to redo the recapitulation. This is proven from the statement of the officer as follows.

"alatnya pernah error, data hipertensi pernah hilang, cara mengembalikannya ya buat laporan lagi dengan ngerekap ulang". (translated into: "the device had an error so I have to redo the recapitulation")

Contrarily, data from Jombang District Health Office have been properly collected and stored, and thus it is available for access at any time.

In conclusion, the stability of monitoring of hypertension in Jombang
District Health Office in 2018 was still considered low because there was one unit experiencing issues in storing the data.

\section{Recapitulation of the Results of Monitoring of Hypertension Cases based on Surveillance Attributes}

Table 2 is the summary of the results of the monitoring of hypertension cases based on surveillance attributes in the Pulo Lor Primary Healthcare Center, Cukir Primary Healthcare Center, and the Jombang District Health Office in 2018.

Table 2. Results on the Monitoring of Hypertension Cases based on Surveillance Attributes

\begin{tabular}{|c|c|c|c|c|}
\hline $\begin{array}{c}\text { Survei } \\
\text { llance Attri } \\
\text { butes }\end{array}$ & $\begin{array}{l}\text { Pulo Lor } \\
\text { HC }\end{array}$ & $\begin{array}{c}\text { Cukir } \\
\text { HC }\end{array}$ & $\begin{array}{c}\text { Jom } \\
\text { bang District } \\
\text { Health Office }\end{array}$ & $\begin{array}{l}\text { Con } \\
\text { clu } \\
\text { sion }\end{array}$ \\
\hline $\begin{array}{l}\text { Simpli } \\
\text { sity }\end{array}$ & high & low & low & low \\
\hline $\begin{array}{l}\text { Flexibi } \\
\text { lity }\end{array}$ & $\begin{array}{c}\text { un } \\
\text { able to be } \\
\text { assesed }\end{array}$ & $\begin{array}{c}\text { un } \\
\text { able to be asse } \\
\text { sed }\end{array}$ & $\begin{array}{l}\text { unable to be } \\
\text { assesed }\end{array}$ & $\begin{array}{c}\text { un } \\
\text { able to be asse } \\
\text { sed }\end{array}$ \\
\hline $\begin{array}{l}\text { Accep } \\
\text { tability }\end{array}$ & low & low & low & low \\
\hline $\begin{array}{l}\text { Sensiti } \\
\text { vity }\end{array}$ & $\begin{array}{c}\text { un } \\
\text { able to be } \\
\text { assesed }\end{array}$ & $\begin{array}{c}\text { un } \\
\text { able to be asse } \\
\text { sed }\end{array}$ & $\begin{array}{c}\text { unable to be } \\
\text { assesed }\end{array}$ & $\begin{array}{c}\text { un } \\
\text { able to be asse } \\
\text { sed }\end{array}$ \\
\hline$P V P$ & $59.4 \%$ & $\begin{array}{c}\text { un } \\
\text { able to be asse } \\
\text { sed }\end{array}$ & $\begin{array}{l}\text { unable to be } \\
\text { assesed }\end{array}$ & low \\
\hline $\begin{array}{l}\text { Repre } \\
\text { sentati } \\
\text { veness }\end{array}$ & $\begin{array}{c}\text { un } \\
\text { able to be } \\
\text { assesed }\end{array}$ & $\begin{array}{c}\text { un } \\
\text { able to be asse } \\
\text { sed }\end{array}$ & $\begin{array}{l}\text { unable to be } \\
\text { assesed }\end{array}$ & $\begin{array}{c}\text { un } \\
\text { able to be asse } \\
\text { sed }\end{array}$ \\
\hline $\begin{array}{l}\text { Timeli } \\
\text { ness }\end{array}$ & $\begin{array}{c}\text { un } \\
\text { able to be } \\
\text { assesed }\end{array}$ & $\begin{array}{c}\text { un } \\
\text { able to be asse } \\
\text { sed }\end{array}$ & $\begin{array}{l}\text { unable to be } \\
\text { assesed }\end{array}$ & $\begin{array}{c}\text { un } \\
\text { able to be asse } \\
\text { sed }\end{array}$ \\
\hline Data Quality & $\begin{array}{l}\text { low }= \\
50 \%\end{array}$ & $\begin{array}{c}\text { un } \\
\text { able to be asse } \\
\text { sed }\end{array}$ & $\begin{array}{c}\text { low }= \\
66.9 \%\end{array}$ & low \\
\hline $\begin{array}{l}\text { Stabi } \\
\text { lity }\end{array}$ & high & low & high & low \\
\hline
\end{tabular}




\section{Problem Identification in the Monitoring of Hypertension Cases}

Problem identification in the monitoring of hypertension case shows several findings. Firstly, the Cukir Primary Healthcare Center experienced difficulty in filling the MSS of hypertension and NCD 42 disease case form. Secondly, the completeness of the routine reports at the Pulo Lor Primary Healthcare Center and Jombang District Health Office was still low. Thirdly, the reporting of the data confirmed/referred back from hospitals to Pulo Lor Primary Healthcare Center was low. Fourth, the absence of complete attendance records and accuracy of the reports found both in the Pulo Lor Primary Healthcare Center, Cukir Primary Healthcare Center and in the Jombang District Health Office was another problem. Finally, the data of hypertension cases in Cukir Primary Healthcare Center had not been stored properly due to an error that causes the loss of the data.

\section{DISCUSSION}

The monitoring of hypertension cases at the Jombang District Health Office in 2018 was assessed using 9 surveillance attributes: simplicity, flexibility, acceptability, sensitivity, positive predictive value, representativeness, timeliness, data quality, and stability (Centers for Disease Control and Prevention, 2013).

\section{Simplicity}

The results show that the implementation of monitoring of hypertension cases in Jombang District Health Office in 2018 was not quite simple. The Cukir Primary Healthcare Center had experienced difficulties in recapitulating the MSS hypertension and NCD 42 disease forms that were reported through Google Drive. The Jombang District Health Office also had difficulty in collecting data as primary healthcare centers did not sumbit their report, further delaying the process of data analysis. This is not in accordance with the Centers for Disease Control and Prevention (CDC) regulation in 2013, where the simplicity of the surveillance system can be seen from data collection to reporting.

However, these results differ from those of Rahmayanti and Hargono's (2017) research which states that the overall integrated development post-based NCD risk factor surveillance system in Surabaya was simple. The difficulties lie, according to their study, in the web portals and servers that were yet to be optimized, thereby hindering electronic recording and reporting. The research of Riley, et al. (2016) found that data collection using the STEPwise approach for Surveillance (eSTEPS) has been proven to simplify the process from manual method or the paperbased method. Additionally, Burchard's (2017) research also stated that overall, the use of the South Australian Monitoring and Surveillance System (SAMSS) system is simple because since 2015, the data in SAMSS have been able to be accessed through South Australia data and the government web portal.

\section{Flexibility}

Flexibility could not be assessed in both primary healthcare centers and the Jombang District Health Office. This was due to the absence of change/alteration in the way of reporting a form and the reporting order. It is in line with Rahmayanti and Hargono's (2017) research which found that the flexibility of the integrated development post-based NCD risk factor surveillance system in Surabaya could not be measured because from 2014 to 2016 as the system did not change. According to the CDC (2013), a surveillance system that has never experienced change cannot be assessed as it cannot prove whether the surveillance system is adaptable.

This is in contrary with the results of Burchard's (2017) research which found 
that the SAMSS system was considered to be a rigid system with little to no flexibility as it could not adjust to the important changes that occur within the society.

\section{Acceptability}

Acceptability in both the primary healthcare centers and the Jombang District Health Office in 2018 was still quite low. This was due to a half completeness of the data in Pulo Lor Primary Healthcare Center and the difficulty in recording hypertension data by Cukir Primary Healthcare Center. The data collected from Cukir Primary Healthcare Center were incomplete and not reported routinely. The Jombang District Health Office also had difficulty in providing complete data, only having a completeness level of $66.9 \%$.

The results of this study were supported by research from Groseclose and Buckeridge (2017), which found that incomplete and poor quality of data made the surveillance systems less acceptable. Another research by Burchard (2017) explains that acceptability in the SAMSS system decreased by $54 \%$ in 2015 , originally $69 \%$ in 2003 . This decline was due to the fact that many people refused to participate in using the SAMSS system, thus making the system less acceptable. However, this is not in line with the research from Rahmayanti and Hargono (2017) which stated that the integrated development post-based NCD risk factor surveillance system had high acceptability because of the participation from agencies outside health parties. Moreover, the results of the surveillance data were also utilized by various parties.

\section{Sensitivity}

The results show that the sensitivity in monitoring cases of hypertension both in primary healthcare centers and in Jombang District Health Office in 2018 could not be assessed. With the absence of health surveys, the institution could not provide data of hypertension cases outside surveillance to act as comparing data. According to the CDC (2013), to measure the sensitivity of a surveillance system, data collection from outside the system is required in order to determine the actual frequency observed from the population and validation of the data collected by the system.

This, however, contradicts the research of Williamson, et al. (2014) which explained that case finding from electronic data recording to identify hypertension with the Canadian Primary Case Sentinel Surveillance Network (CPCSSN) was quite comprehensive with a sensitivity value of $84.9 \%$.

\section{Positive Predictive Value}

The positive predictive value in the results of this study could be assessed from Pulo Lor Primary Healthcare Center with a value of $59.4 \%$. According to the CDC (2013), a low positive predictive value means there were no cases that could be investigated because it may cause an unnecessary intervention.

This is not in line with the research of Williamson et al. (2014) which shows that positive predictive value was quite accurate at $92.9 \%$ according to the Canadian Primary Case Sentinel Surveillance Network (CPCSSN).

\section{Representativeness}

The representativeness of monitoring of hypertension cases were unable to be assessed. In 2018, there was no health survey conducted, thus the surveillance data could not represent the population. However, this is different from Rahmayanti and Hargono's (2017) research which stateed that the integrated development post-based NCD risk factor surveillance system was only time representative, not yet of the people and place variables. Burchard's (2017) research stated that the representative of the SAMSS system was still considerably low because 
certain groups were under-represented in the survey.

The research of Norton et al. (2016) also found that an intensive service surveillance system using electronic Record for Intensive Care (e-RIC) could capture and inform disease patterns that occur in New South Wales Australia and represent a real situation.

\section{Timeliness}

The timeliness of the research results could not be assessed because both primary healthcare centers and the Jombang District Health Office did not use any timekeeping or attendance system on the reports.

The timeliness of NCD surveillance was oriented towards planned actions or programs. The integrated development post-based NCD risk surveillance system in Surabaya has been considered timely if relayed to the officers of the primary healthcare centers to the district health office that have planned the schedule (Rahmayanti and Hargono, 2017). Meanwhile, according to Burchard's (2017) research, the timeliness in the SAMSS system could be seen from the monthly reporting and routine reports as the South Australia Health proceeded.

\section{Data Quality}

The data quality of the research subjects were low due to the unachieved completeness of the reports less than $80 \%$. The reports from the Pulo Lor Primary Healthcare Center were only $50 \%$ completed, and the Jombang District Health Office only achieved $66.9 \%$.

Centers for Disease Control and Prevention (2013) stated that the quality of data in a surveillance system depicts the completeness and accuracy of the data recorded in the system itself. If the data quality is low, it will cause the data to become invalid (Chen et al, 2014); hence, it was less acceptable and less representative of the population (Groseclose \&
Buckeridge, 2017). Based on research by Rahmayanti and Hargono (2017), the completeness of data could be assessed from the reports of all activities disclosed to the primary healthcare center monthly.

\section{Stability}

The results show that the stability in the monitoring of hypertension cases in 2018 were low. The Cukir Primary Healthcare Center encountered problems in storing data of hypertension cases. The data storage device experienced an error resulting in the loss of data.

The results of this research differ from Rahmayanti and Hargono's (2017) research. They found that the integrated develompent post-based NCD risk factor surveillance system was high in stability because the data collected were managed and stored properly in a register book and the NCD web portal. If something was about to happen, that data will remain safe and can be traced back. A research by Norton et al. (2016) also stated that the eRIC system was high in stability as it could store and provide data if needed at any time. The data on the eRIC system were planned to reach $99.9 \%$ in availablility. Furthermore, according to research conducted by Burchard (2017), the SAMSS system is also highly stable because the system has been running since 2002 and has never experienced any major disruptions.

\section{Alternative Solution}

Alternative solutions which can be considered to overcome the issues in the monitoring of hypertension cases found in Pulo Lor Primary Healthcare Center, Cukir Primary Healthcare Center, and Jombang District Health Office, were as follows. First, the institutions need to conduct training for officers who are still experiencing difficulties in recording information on the MSS hypertension and NCD 42 disease case forms to improve the completeness of data. Second, they need to implement a rewarding system by giving 
certificates to the officers who report regularly, properly, completely, and on time. Third, the institutions need to establish partnerships and coordinate with referral hospitals better to be able to report back to the primary healthcare center according to the data referenced. Fourth, they should create and apply attendance records for assessing the accuracy and completeness of the reports received from the source. Fifth, they have to back up data online on google drive to restore it if at any time loss of data occurs due to an error in the data storage device.

\section{CONCLUSION}

Out of nine surveillance attributes in Jombang District Health Office in 2018, simplicity, acceptability, positive predictive value, data quality, and stability were considered low. Whereas, flexibility, sensitivity, representation, and timeliness could not be assessed. The obstacles found in the monitoring process were the absence of attendance records to assess the completion and accuracy of the reports in each unit. This study suggests to have and provide attendance or timekeeping post in each reporting unit, and thus the data could be used as planning materials for coping with hypertension cases.

\section{REFERENCES}

Burchard, A. 2017. Evaluation of the South Australian Monitoring and Surveillance System. South Australia: Government of South Australia.

CDC. 2013. Evaluating an NCD-Related Surveillance System. Atlanta: Department of Health \& Human Services USA.

Chen, H., Hailey, D., Wang, N., \& Yu, P. 2014. A Review Of Data Quality Assessment Methods For Public Health Information Systems. International Journal of Environmental Research and Public Health, 11(5): pp.5170-5207. https://doi.org/10.3390/ijerph1105051 70

East Java Province Health Office. 2019. East Java Province Health Profile in 2018. Surabaya: East Java Province Health Office.

Groseclose, S. L., \& Buckeridge, D. L. 2017. Public Health Surveillance Systems: Recent Advances In Their Use And Evaluation. The Annual Review of Public Health, Volume 38, pp.57-79. Available in: https://doi.org/10.1146/annurevpublhealth-031816-044348 [citation 25 Juni 2019].

Jombang District Health Office. 2018. Government Agency Performance Accountability Report (LAKIP) in 2017. Jombang: Jombang District Health Office.

Jombang District Health Office. 2019. Jombang District Health Profile in 2018. Jombang: Jombang District Health Office.

Ministry of Health RI. 2014. Regulation of the Ministry of Health RI Number 45 in 2014 about the Implementation of Health Surveillance. Jakarta: Ministry of Health RI.

Ministry of Health RI. 2018. National Report on Basic Health Research (Riskesdas) in 2018. Jakarta Pusat: Ministry of Health RI.

Norton, S., Cordery, D. V, Abbenbroek, B., Ryan, A., \& Muscatello, D. 2016. Towards Public Health Surveillance Of Intensive Care Services In NSW, Australia. Public Health Research \& Practice, 26(3): pp.1-8. Available in: https://doi.org/10.17061/phrp2631633 [citation 27 Juni 2019].

Peberdy, V. 2016. Hypertension: Putting The Pressure On The Silent Killer. IFPMA.

Rahmayanti, E., \& Hargono, A. 2017. Implementation of Non Communicable Disease Risk Factors Surveillance in Posbindu Surabaya based on Surveillance Attribute (Study in Surabaya) Jurnal Berkala 
Epidemiologi, 5(3): pp.276-285.

Riley, L., Guthold, R., Cowan, M., Savin,

S., Bhatti, L., Armstrong, T., \& Bonita,

R. 2016. The World Health

Organization Stepwise Approach To

Noncommunicable Disease Risk-

Factor Surveillance: Methods,

Challenges, And Opportunities.

American Journal of Public Health, 106(1): pp.74-78. Available in: https://doi.org/10.2105/AJPH.2015.30 2962 [citation 24 Juni 2019].

WHO. 2013. High Blood Pressure: Global and Regional Overview.

Williamson, T., at al. 2014. Validating The 8 CPCSSN Case Definitions For Chronic Disease Surveillance In a Primary Care Database Of Electronic Health Records. Annals of Family Medicine, 12(4): pp.367-372. Available in: https://doi.org/10.1370/afm.1644 [citation 23 Juni 2019]. 